\title{
O papel da desobediência civil em sociedades de massas não-totalitárias em Arendt
}

\author{
The role of civil disobedience in non-totalitarian mass societies in \\ Arendt*
}

\author{
Nathalia Rodrigues da Costa \\ nathaliarodrigues1304@gmail.com \\ (Universidade Estadual de Campinas, São Paulo, Brasil)
}

\begin{abstract}
Resumo: Margareth Canovan e Jean Cohen e Andrew Arato apresentam críticas à análise de Hannah Arendt da sociedade de massas. Tais críticas convergem para um diagnóstico: a análise de Arendt é influenciada pela sua abordagem do totalitarismo e isso teria prejudicado sua atenção para os potenciais democráticos das sociedades democráticas contemporâneas. $\mathrm{Na}$ contramão dessas críticas, defende-se neste artigo que, se interpretarmos o tema da sociedade de massas a partir da distinção entre sociedade de massas não-totalitária e sociedade de massas totalitária, enxergamos a atenção de Arendt para os potenciais democráticos das sociedades não-totalitárias ainda massificadas, sobretudo, na sua análise dos movimentos de Desobediência Civil.
\end{abstract}

Palavras-chave: Hannah Arendt; Keywords: Hannah Arendt; civil disobedience; desobediência civil; sociedade de massas.

\begin{abstract}
Margareth Canovan and Jean Cohen and Andrew Arato criticize Hannah Arendt's analysis of mass society. Such criticisms converge on a diagnosis: Arendt's analysis is influenced by her approach of totalitarianism and this would have undermided her attention to the democratic potentials of contemporary democratic societies. On the opposite way, it is argued in this article that if we interpret the theme of mass society from the distinction between non-totalitarian mass society and totalitarian mass society, we see Arendt's attention to the democratic potentials of the non-totalitarian societies still massified, especially in their analysis of the movements of Civil Disobedience.
\end{abstract}

DOI: http://dx.doi.org/10.11606/issn.2318-9800.v24i2p13-28

A primeira seção deste artigo preocupa-se em explicitar as críticas dos intérpretes e comentadores a respeito da análise arendtiana da sociedade de massas. A segunda seção parte da premissa de que sociedade de massas e totalitarismo, embora imbricados na análise de Arendt em As origens do totalitarismo (1951), são fenômenos distintos e têm, cada um, sua importância própria na teoria da autora.

\footnotetext{
* O presente artigo é fruto da dissertação de mestrado intitulada "A sociedade de massas em Hannah Arendt" defendida no Instituto de Filosofia e Ciências Humanas (IFCH) da Unicamp em 2018 . Agradeço à Fundação de Amparo à Pesquisa do Estado de São Paulo (Fapesp) pelo financiamento das pesquisas de mestrado (2015/25277-0) e doutorado (2018/00645-5). Agradeço também ao Grupo de Estudos de Filosofia Política da Unicamp, especialmente a: Leonardo Rennó, Nádia Junqueira Ribeiro, Ana Claudia Lopes Silveira, Otávio Vasconcelos Vieira, Laíssa Ferreira, Renata Rômolo Brito e Yara Adario Frateschi, com os quais compartilhei a primeira versão deste artigo e cujas críticas e contribuições foram valiosas. Agradeço ainda aos pareceristas que contribuíram para uma melhor versão deste artigo.
} 
Desse modo, defendo que só é possível compreender a potência crítica da análise da sociedade de massas nas obras posteriores à obra de 1951, se diferenciarmos sociedade de massas não-totalitária de sociedade de massas totalitária. Explicada essa diferenciação crucial na interpretação do tema da sociedade de massas, parto para a terceira e última seção deste artigo, onde abordo o fenômeno da desobediência civil como potencialmente capaz de fazer frente aos bloqueios impostos à política pela sociedade de massas em contextos democráticos.

\section{Críticas à interpretação arendtiana da sociedade de massas ${ }^{1}$}

Em The Contradictions of Hannah Arendt's Political Thought (1978), Canovan deixa clara sua discordância com a crítica arendtiana ao sistema de partidos quanto à restrição da ação política dos cidadãos. ${ }^{2}$ Para a comentadora, uma das razões da posição de Arendt é que: “ela [Arendt] continuou a interpretar a política na América dos anos de 1960, em alguma medida, em termos de uma teoria herdada da sociedade de massas e seus perigos políticos" (Canovan, 1978, p. 22). Nesta passagem, Canovan parece não concordar com a posição arendtiana de que o mundo democrático contemporâneo vive sob as condições da sociedade de massas e parece desconsiderar as suas ameaças. Arendt, porque continua a interpretar a política nos termos da teoria da sociedade de massas, teria exagerado no seu diagnóstico da década de 1960 ou padeceria de um anacronismo após o fim da Segunda Guerra Mundial.

É notável que Canovan reviu muitas das suas posições de 1978 na sua obra

1 Todas as citações de Margareth Canovan e de Jean Cohen e Andrew Arato mobilizadas neste artigo são traduções minhas.

2 No artigo de 1978, Canovan considera que Arendt defenda a substituição da democracia representativa pelo sistema de conselhos (cf. Canovan, 1978, p. 23) e afirma que esta proposta de Arendt é uma irresponsabilidade utópica (cf. idem, p. 8). De modo breve e pontual, não acredito que a intenção de Arendt ao criticar o sistema representativo dos partidos tenha sido propor uma substituição deste pelo sistema de conselhos, que significaria a substituição das democracias representativas por uma democracia direta. Os conselhos são abordados por Arendt para fazer a crítica à restrição da participação política dos cidadãos gerada pela burocratização da máquina partidária e pela falsa ideia de que a política é o espaço de atuação do especialista, no caso, dos representantes eleitos, e não do cidadão comum. Os conselhos eram as instituições que, na contramão do distanciamento do cidadão do âmbito político, surgiram espontaneamente a partir da organização do próprio povo e forneceram espaço para a participação política. Em sua obra de 1992, Canovan suaviza o tom de 1978 segundo o qual Arendt defenderia a substituição do sistema de partidos pelo sistema de conselhos. Em 1992, a comentadora afirma que não se poderia ter certeza se Arendt consideraria os conselhos uma possibilidade prática para o futuro (cf. Canovan, 1992, p. 236). Contudo, Canovan deixa clara sua preocupação com a possível substituição dos partidos pelos conselhos ao elencar as consequências da substituição da democracia representativa pela democracia direta. (idem, pp. 137-138). Ao enfatizar sua preocupação com a substituição da democracia representativa pela democracia direta, Canovan desvia a atenção daquilo que, como já exposto, parece ser a intenção de Arendt ao abordar os conselhos: criticar a restrição participativa dos cidadãos nas sociedades democráticas baseadas no sistema partidário. Para uma discussão mais aprofundada do papel dos conselhos na obra arendtiana, fundamentalmente em Sobre a revolução (1963), cf. Frateschi, 2016. 
de 1992, A Reinterpretation of her Political Thought. Contudo, mesmo nesta sua reinterpretação, Canovan parece ainda considerar que a teoria da sociedade de massas de Arendt não seria adequada para analisar as sociedades democráticas contemporâneas porque, ao ressoar suas análises do totalitarismo, a teoria da sociedade de massas não permitiria a Arendt enxergar por completo os ganhos democráticos das sociedades contemporâneas. Vejamos:

Em A Reinterpretation of her Political Thought, ao abordar a análise de Arendt do advento do social, Canovan apresenta uma explicação que o compreende a partir de duas vertentes, uma econômica e outra cultural. A primeira vertente considera o social como a transformação dos interesses materiais ligados à manutenção do processo vital em preocupação coletiva (cf. Canovan, 1992, p. 118). O social significa também a transformação das atividades privadas de produção e consumo na finalidade da política. Nesse sentido, o campo da política seria aquele responsável por promover o desenvolvimento das atividades ligadas ao processo de manutenção da vida (cf. idem, ibidem) e, por consequência, o Estado seria a instituição responsável por proteger e promover os interesses privados (cf. idem, ibidem). Quanto à vertente cultural, Canovan considera que Arendt foca no que se convencionou chamar de "eventos sociais, status social" (idem, p.119). Para a comentadora, o social também se refere "à arena do consumo público, da moda, do sucesso social” (idem, ibidem), cuja origem Arendt encontrou na "alta sociedade" do século XVIII. Dessa forma, o problema para Canovan é que:

A sociedade dos salões parisienses do século XVIII que Rousseau denunciou incluía apenas uma pequena parte da população, mas pareceu a Arendt que desde aquele tempo a infecção se espalhou como incêndio, alastrando-se no século dezenove dentro da sociedade burguesa (...). No século XX, à medida que o lazer e o consumo se expandiram, os mesmos traços sociais se espalharam de tal forma que toda população estava se comportando como aristocratas do antigo regime, devotados ao consumo conspícuo, à conformidade à moda e obcecados por seus status sociais (idem, ibidem).

$\mathrm{Na}$ sua interpretação, a vertente cultural tem a ver com "a absorção de toda a população em formas de vida anteriormente características da 'alta sociedade'” (idem, pp. 119-120) e seria “castigada pelos teóricos da 'sociedade de massas"” (idem, p. 118), porque está "preocupada com a uniformidade da moral e do estilo de vida" (idem, ibidem), ou seja, porque a teoria da sociedade de massas de Arendt está embasada na ideia de que a sociedade se comporta, o que Canovan claramente não concorda. De acordo com Canovan, “a justaposição dessas duas vertentes [econômica e cultural] está ligada com a sua teoria do totalitarismo" (idem, ibidem) e "o seu foco fundamental na compreensão do totalitarismo de um modo particular a leva a ver uniformidade monolítica nas sociedades ocidentais onde outros observadores veem diversidade e pluralismo" (idem, p.121). 
Por sua vez, Cohen e Arato no quarto capítulo de Civil Society and Political Theory (1995) argumentam que Arendt, ao criticar a forma organizacional de "movimentos" na obra de 1951, não teria enxergado o papel mediador dos movimentos sociais entre as esferas pública e privada nas sociedades contemporâneas. Nesta crítica em questão, Arendt tem em mira o caráter ideológico e o discurso de ódio à política dos movimentos totalitários. A autora mostra que esse discurso de ódio era enfatizado justamente quando a forma de movimento era enaltecida em lugar da forma organizacional de partidos políticos. Os movimentos totalitários diziam estar acima dos partidos e não terem nenhuma ligação com qualquer instituição; assim, conseguiram angariar um apoio massivo da população ao atingirem exatamente aquela parcela (não pequena) que não se sentia representada politicamente, que estava fora do alcance da representação política e com a qual os partidos não se importavam devidamente (cf. 1989, pp. 361-362). Em decorrência dessa crítica, os intérpretes consideram que Arendt não teria percebido o potencial dos movimentos sociais de reinventar ou expandir a esfera pública (cf. Cohen e Arato, 1995, p. 200) e interpretam sua posição da seguinte maneira:

Adotando a versão radicalizada da crítica pluralista da sociedade de massas que usa os movimentos totalitários como paradigma, Arendt está convencida de que os movimentos sociais aceleram e completam a destruição do domínio público e do privado pelo domínio social. Isto é, os próprios movimentos sociais alimentam e ajudam a criar e perpetuar a atomização e a despolitização característica da sociedade de massas. (...) os movimentos sociais são proto-totalitários e a realização totalitária do advento da sociedade não é possível sem eles (idem, pp. 199-200, grifos meus).

Os intérpretes consideram que a análise de Arendt dos movimentos sociais tem como "paradigma" as experiências dos movimentos totalitários e que, por isso, ela os consideraria "proto-totalitários". Cohen e Arato, então, veem a análise de Arendt sobre os movimentos sociais como falha e afirmam: "Se Arendt está correta sobre os movimentos sociais enquanto tais, seu sonho de reavivar o republicanismo pode ser declarado finalmente morto" (idem, p. 200), pois, sem enxergar qualquer papel democrático nos movimentos sociais, que se consolidaram como atores políticos das democracias representativas contemporâneas, não seria possível recuperar a experiência da liberdade pública (cf. idem, ibidem).

\section{Sociedade de massas e a cristalização dos regimes totalitários}

O incômodo de Canovan com a insistência de Arendt em tratar da política dos anos 1960 nos termos da sociedade de massas ou a interpretação de Cohen e Arato segundo a qual Arendt tem como paradigma das suas críticas aos movimentos sociais os movimentos totalitários são de certo modo compreensíveis porque a análise da autora sobre o tema foi realizada com maior fôlego na obra As origens do totalitarismo 
de 1951, sobretudo na Parte III, intitulada “Totalitarismo". O título dá a pista sobre a intenção da autora: discorrer sobre os governos totalitários, uma vez que já realizou ao longo da obra o esforço de explicitar os elementos histórico-filosóficos que contribuíram para a construção de uma atmosfera política, cultural e social propícia à cristalização de regimes baseados na ideologia e no terror ao tratar do papel dos elementos do Anti-semitismo e do Imperialismo. A Parte III trata, então, de outro elemento importante para a cristalização do domínio total: a sociedade de massas. Contudo, um olhar mais atento aos argumentos da autora percebe que, embora a sociedade de massas tenha sido solo fértil para o totalitarismo, não há entre eles qualquer relação causal ou fatalista. Pelo contrário, a sociedade de massas precedeu a sociedade totalitária e a sociedade de massas totalitária foi forjada a partir da intensificação das características da sociedade de massas previamente constituída. ${ }^{3}$ Desse modo, sociedade de massas não é sinônimo de sociedade totalitária.

A destruição gerada pela Primeira Guerra Mundial foi o prelúdio do fenômeno crucial para a constituição de uma sociedade de massas no continente europeu - o colapso das classes sociais do século XX - e para a transformação da geração que a precedeu em massa (cf. Arendt, 1989, p. 378). Terminada a guerra, restaram destroços, inflação, desemprego, a substituição dos movimentos de unificação nacionais pelos movimentos totalitários, o desmoronamento do sistema de classes sociais, o consequente esfacelamento do sistema partidário e, inevitavelmente, uma massa de homens e mulheres assolados pelas consequências da guerra e que tinham como principais características o isolamento e o sentimento de serem absolutamente supérfluos.

O desemprego, a inflação e a destruição gerados pela guerra agravaram exponencialmente uma atmosfera social apolítica construída pela absorção dos padrões burgueses de vida por todas as classes sociais ao longo dos séculos XVIII e XIX. Esses padrões eram caracterizados pelo individualismo, pelo incentivo ao consumo, à competitividade e ao sucesso individual a qualquer custo; e foram originados pela expansão industrial e econômica promovida pela classe burguesa dentro dos Estadosnação durante esses dois séculos. A confiança na expansão econômica ficou conhecida como "A Idade de Ouro da Segurança” (idem, p. 72) e foi marcada pela crescente despreocupação com as questões públicas; o Estado deixou de ser visto como aquela instituição que governa classes distintas, para ser visto como aquela instituição

3 Não abordarei neste artigo o modo como as características da sociedade de massas foram intensificadas e utilizadas pelos líderes dos movimentos e regimes totalitários para que a sociedade de massas totalitária fosse forjada. Contudo, importa dela ter sido forjada. Isso significa que ela foi moldada, fabricada por mãos humanas e, portanto, a transformação de uma sociedade de massas em uma sociedade de massas totalitária não é natural, tampouco necessária. Desse modo, quando falamos de sociedade de massas, não estamos necessariamente falando de sociedade totalitária. Irei me concentrar em mostrar certas condições presentes na sociedade de massas não-totalitária que foram solo fértil ao totalitarismo. 
que deve garantir a livre concorrência e a segurança da propriedade privada de indivíduos privados e isolados. Segundo Arendt: "A Europa estava demasiado ocupada em expandir-se economicamente para que qualquer nação ou camada social levasse a sério as questões políticas" (idem, ibidem). Contribuía para a intensificação dessa atmosfera apolítica a incapacidade do sistema representativo dos partidos políticos em efetivamente representar as demandas dos cidadãos. Desse modo, a absorção dos padrões burgueses combinada à crise da representação promoveram o afastamento do indivíduo da vida pública, obliterando o próprio reconhecimento desse cidadão como parte de grupos ou classes sociais com demandas e interesses específicos.

0 reconhecimento do pertencimento às classes sociais permitia aos indivíduos constituírem interesses comuns e canalizá-los à esfera pública na forma de demandas políticas. O conflito de demandas plurais advindas de classes sociais ou grupos distintos era o que constituía e assegurava a trama organizacional da sociedade. Contudo, "a sociedade competitiva e de consumo criada pela burguesia gerou apatia, e até mesmo hostilidade em relação à vida pública" (idem p. 363), fazendo com que os interesses comuns fossem paulatinamente substituídos pelos interesses estritamente individuais. Desse modo, apesar de existirem classes sociais distintas, elas não eram mais capazes de abarcar interesses públicos comuns e trazê-los à esfera pública para se tornarem demandas passiveis de serem contempladas, pois as pessoas, ao perderem a consciência do pertencimento à classe, não se enxergavam como tendo interesses comuns compartilháveis, não se enxergavam como pertencentes a um mundo comum, mas como indivíduos privados, com interesses estritamente privados e, portanto, isolados uns dos outros.

"Esse esquisito estado de coisas durou exatamente até 1914, quando, pelo próprio fato da guerra, desmoronou a confiança das massas no caráter providencial da expansão econômica" (idem, p. 72). Findada a guerra, a Idade de Ouro da Segurança mostrou-se ilusória e, ao ruir, atingiu a todos, indiscriminadamente. Como resultado, o sistema de classes sociais, já bastante incapaz de exercer seu papel político de congregar interesses comuns e evidenciar a pluralidade de interesses conflitantes que constituem a sociedade, porque dominado pela burguesia (cf. idem, p. 364), se torna, agora, completamente obsoleto. Terminada a guerra, o que se tem é uma massa indistinta de homens e mulheres desesperados, insatisfeitos e sem laços comuns. 0 colapso do sistema de classes sociais deixou em evidência o caráter apolítico da sociedade dos Estados-nação e "destruiu toda a urdidura de fios visíveis e invisíveis que ligavam o povo à estrutura política" (idem, ibidem). Foi exatamente "nessa atmosfera de colapso das classes que se desenvolveu a psicologia do homemde-massa da Europa" (idem, p. 365). As massas passaram a ser caracterizadas tanto pelo isolamento, uma vez que já se retiraram há muito tempo do espaço público, do espaço destinado à ação e ao diálogo uns com os outros sobre o mundo comum 
que compartilham, quanto pelo sentimento de fracasso individual e superfluidade. A "consciência da desimportância e da dispensabilidade deixava de ser a expressão da frustração individual e tornava-se um fenômeno de massa” (idem, ibidem).

As massas não se unem pela consciência de um interesse comum e falta-lhes aquela específica articulação de classes que se expressa em objetivos determinados, limitados e atingíveis. 0 termo massa só se aplica quando lidamos com pessoas que, simplesmente devido ao seu número, ou à sua indiferença, ou a uma mistura de ambos, não se podem integrar numa organização baseada no interesse comum, seja partido político, organização profissional ou sindicato de trabalhadores. Potencialmente, as massas existem em qualquer país e constituem a maioria das pessoas neutras e politicamente indiferentes, que nunca se filiam a um partido e raramente exercem 0 poder de voto (idem, p. 361).

Após mostrar a importância da ausência de interesses públicos comuns, de laços sociais e políticos entre os indivíduos para a constituição da massa, enquanto um corpo amorfo de indivíduos isolados, apáticos e neutros politicamente, Arendt mostra como os movimentos totalitários encontraram solo fértil nessa atmosfera de caos social, econômico e político, e como as características das massas absolutamente individualizadas e isoladas, que Arendt denominará de fenômeno de "atomização social e individualização extrema" (idem, p. 366), precederam os movimentos totalitários e foram cruciais para o seu fortalecimento. Ela diz:

A atomização social e a individualização extrema precederam os movimentos de massa, que muito antes de atraírem, com muito mais facilidade os membros socializáveis e não-individualistas dos partidos tradicionais, acolheram os completamente desorganizados, os típicos não-alinhados que, por motivos individualistas, sempre se haviam recusado a reconhecer laços ou obrigações sociais (idem, ibidem).

As condições de uma massa atomizada e individualizada favoreceram o surgimento e o fortalecimento dos movimentos totalitários que, por sua vez, preparam as bases sociais e políticas para a constituição de regimes totalitários. Essas condições são tão importantes que, onde não existiam, foram forjadas, como na Rússia de Stálin.

Os movimentos totalitários dependiam menos da falta de estrutura de uma sociedade de massas do que das condições específicas de uma massa atomizada e individualizada, como se pode constatar por uma comparação do nazismo com o bolchevismo, que surgiram em seus respectivos países em circunstâncias muito diversas. A fim de transformar a ditadura revolucionária de Lênin em completo regime totalitário, Stálin teve primeiro que criar artificialmente aquela sociedade atomizada que havia sido preparada para os nazistas na Alemanha por circunstâncias históricas (idem, p. 368).

A partir do exposto, gostaria de destacar dois pontos. Primeiro, quando Arendt aborda a sociedade de massas, é equívoco considerar que ela se refere à sociedade de massas na sua forma totalitária, uma vez que a conformação de uma sociedade de massas é, inclusive, anterior à consolidação dos regimes totalitários. Segundo, há um esforço da autora em mostrar que não é a estrutura de uma sociedade de massas, 
mas são as condições específicas de uma massa individualizada e atomizada - que, inclusive, podem ser criadas artificialmente - que contribuem para a formação de regimes totalitários. Portanto, da conformação de uma sociedade de massas não se segue necessariamente ou fatalmente a conformação de um regime totalitário. Há, antes, um espaço para a ação política considerável que diferencia uma sociedade de massas não-totalitária de uma sociedade de massas totalitária. E, a meu ver, quando Arendt trata os contextos políticos de 1960 como contextos massificados, ela está apontando para os perigos de uma sociedade apolítica, como foi a sociedade anterior aos regimes totalitários, marcada, por exemplo, pelo esvaziamento do espaço público, pela substituição da ação e do diálogo conjunto pelo comportamento em conformação a certos padrões sociais (cf. idem, p. 364). Mas está ainda apontando que, mesmo em sociedades democráticas, corre-se sempre o perigo da consolidação de uma mentalidade individualista e autointeressada e da constituição, de um lado, de setores da população apáticos politicamente e, de outro, de setores que reagem violentamente às instituições políticas, devido à crise do sistema representativo dos partidos (cf. idem, pp. 362, 365); características de uma sociedade de massas que bloqueiam e minam a própria democracia. Desse modo, defendo que diferenciar sociedade de massas não-totalitária de sociedade de massas totalitária seja não só condizente com a letra do texto arendtiano, como nos capacita a entender melhor os perigos da massificação e a necessidade constante de recriar e alargar os espaços políticos de ação conjunta que Arendt tanto nos chama a atenção, como, por exemplo, na sua análise da desobediência civil.

\section{A potência da desobediência civil}

Ocorrido nos Estados Unidos entre as décadas de 1960 e 1970, o movimento de desobediência civil é um dos eventos do mundo moderno que se apresenta para Hannah Arendt como os novos sinais de esperança e a fé na política, na possibilidade de restaurar a sua dignidade ${ }^{4}$ e de transformar o contexto de apatia política e letargia da sociedade democrática representativa dos Estados Unidos.

\footnotetext{
4 Trato o movimento de desobediência civil como um novo sinal de esperança para a restauração da dignidade da política porque acredito que o primeiro sinal dessa esperança apareceu para Arendt ainda em meio ao total fechamento da esfera pública durante o regime totalitário russo, quando o movimento dos trabalhadores, junto a outras parcelas da sociedade húngara, encenou uma das estórias mais importantes do mundo moderno ao ser protagonista do evento da Revolução Húngara de 1956 (cf. Arendt, 1958, p. 5 e ss). Para a autora, mesmo com o trágico fim desse evento após a desmedida reação russa, o sacrifício daqueles que lutaram não foi em vão, porque demonstrou ao mundo que o elã político ainda não havia morrido, mesmo sob as condições da impossibilidade da política no totalitarismo. É esse elã político, em meio a um contexto de isolamento, ou seja, de destruição do espaço público, e de completa solidão, porque nem mesmo a esfera privada estava resguardada da dominação exercida pela ideologia e pelo terror, que Arendt enxerga como o primeiro grande sinal de esperança de recriar as condições para a política e de restaurar o seu domínio próprio.
} 
A esperança na política está ancorada teoricamente na categoria da natalidade ${ }^{5} \mathrm{e}$ o tom de esperança que fecha a obra de 1951 prova que Arendt, a despeito de qualquer contexto político de fechamento, deposita nas pessoas a possibilidade da mudança, da transformação, pelo simples fato de constituírem o singularmente novo no mundo ao nascerem. Porque são natais, podem vir a iniciar um novo começo neste mundo ao qual foram lançados e no qual se constituem como indivíduos e cidadãos. "O começo, antes de tornar-se evento histórico, é a suprema capacidade do homem; politicamente, equivale à liberdade do homem (...). Cada novo nascimento garante esse começo; ele é, na verdade, cada um de nós" (Arendt, 1989, p. 531). A liberdade é a própria capacidade de começar algo completamente novo, de agir. Não é trivial que a natalidade seja a categoria central do pensamento político arendtiano (cf. Arendt, 2014, p. 10), pois a ação retira sua potência e seu ônus do próprio fato da natalidade. Sua potência está em poder iniciar junto à pluralidade das pessoas algo inesperado; seu ônus, compreendido como a própria fragilidade dos assuntos humanos, repousa no fato das ações se tornarem completamente incontroláveis uma vez iniciadas. A novidade do fato da natalidade torna o campo dos assuntos humanos frágil e, ao mesmo tempo, o salva da pretensão estatística de tudo padronizar e prever, características da sociedade de massas. 0 novo sempre aparece na forma de um milagre (cf. idem, p. 222).

O milagre que salva o mundo, o domínio dos assuntos humanos, de sua ruína normal, "natural” é, em última análise, o fato da natalidade, no qual a faculdade da ação se radica ontologicamente. Em outras palavras, é o nascimento de novos seres humanos e o novo começo, a ação de que são capazes em virtude de terem nascido. Só a plena experiência dessa capacidade pode conferir aos assuntos humanos fé e esperança (idem, p. 308).

Fé nos assuntos humanos significa confiança na capacidade de ação das pessoas, significa confiança na capacidade da ação em gerar poder e, por meio de sua criação e permanência, manter a existência do espaço de aparências, que é o domínio público. A fé ou a confiança na capacidade da ação corresponde à fé na política, uma vez que apenas a ação e o discurso conferem dignidade à política, dignidade essa que, de acordo com Arendt, "ainda hoje não desapareceu completamente" (idem, p. 256). Desse modo, ter fé e esperança nos assuntos humanos é ter confiança na capacidade das pessoas de gerar novos inícios e acreditar que as ações que iniciam

\footnotetext{
5 Factualmente esta esperança está ancorada no movimento dos trabalhadores que, para Arendt, desde as revoluções de 1848 até a Revolução Húngara de 1956 "foram o único grupo no cenário político que, além de defender seus interesses econômicos, travou uma batalha inteiramente política" (Arendt, 2014, p. 273). Essa batalha política só pôde ser travada pela classe operária porque ela estava organizada, isto é, porque tinha demandas claras e objetivas advindas não dos programas e das ideologias dos partidos que as representavam, mas de seus próprios integrantes. Suas demandas extrapolavam as reivindicações da classe, como regulamentação das horas de trabalho e direito ao voto, por exemplo, defendidas pelos sindicatos, e se tornavam efetivamente políticas quando apresentavam ideias próprias acerca da forma de organização do governo democrático, sobre a qual propunham uma "nova forma de governo: o sistema de conselhos populares, em substituição ao sistema partidário continental” (idem, p. 270).
} 
em concerto podem interromper ou quebrar uma cadeia causal de eventos iniciados anteriormente, porque é da natureza da ação "romper o comumente aceito e alcançar o extraordinário" (idem, ibidem). A fé na política é propriamente a fé na capacidade da mudança propiciada pela grandeza da ação e gerada toda vez que as pessoas agem e dialogam umas com as outras e criam poder.

Após a Revolução Húngara aparecer e iluminar o cenário da sociedade de massas totalitária como um sinal de esperança de recuperação da dignidade da política num contexto de total fechamento, a esperança no novo, a esperança e a fé de que podemos sempre começar novamente a construir ou reconstruir as condições da política permaneceu. Incentivada pelo legado húngaro, e ciente de que após o fim dos regimes totalitários a maioria dos países ocidentais organizou-se em democracias representativas baseadas no sistema partidário, a autora percebe que os perigos oferecidos à esfera política não foram dissipados sob as democracias. "Hoje, os problemas centrais do mundo consistem na organização política da sociedade de massas e na integração política do poder tecnológico" (Arendt, 2008, p. 443). Importa à autora pensar se, mesmo diante das barreiras impostas por uma sociedade de massas não-totalitária, ainda é possível que "as noções revolucionárias de felicidade pública e liberdade pública” (Arendt, 2011, p. 185) sejam capazes de resistir "às palhaçadas frívolas de uma sociedade interessada no enriquecimento e no consumo, ou se cederá sob a pressão da riqueza" (idem, ibidem). Para Arendt, "atualmente, os sinais que justificam a esperança empatam com os sinais que inspiram medo" (idem, ibidem).

O diagnóstico de Arendt da sociedade de massas não-totalitária, com especial atenção à sociedade americana, aponta para sério prejuízo da ação, do discurso, enfim, da política. No entanto, a fé na capacidade de mudança reapareceu para a autora nas décadas 1960 e 1970 nos Estados Unidos com os movimentos de desobediência civil: o movimento estudantil e o movimento pelos direitos civis. Esses movimentos alargaram a esfera pública americana com a ação conjunta de várias pessoas e a tornaram audível por meio das palavras pronunciadas em forma de demandas políticas. Os atos e palavras dos cidadãos apareceram como um sinal de esperança capaz de retirar a sociedade americana da letargia característica da massificação. Vejamos:

O ensaio “Desobediência Civil”, presente em Crises da República (1969), põe em evidência o encolhimento da esfera pública e a necessidade de mudanças nos Estado Unidos devido à crise constitucional no fim da década de 1960 e início de 1970. Além da crise de representação e da ausência de garantia clara da Constituição norte-americana à participação política dos cidadãos (cf. Arendt, 2013, pp.74-75), soma-se a existência de leis anticonstitucionais, como a Décima Quarta Emenda da Constituição, segundo a qual os “"negros não são e não podem ser cidadãos no 
sentido da constituição federal'” (idem, p. 81); e ações governamentais legalmente duvidosas, como a entrada do país na Guerra do Vietnã. Como resposta ao cenário político de crise, surgem no país movimentos de desobediência civil, que aparecem quando

um número significativo de cidadãos se convence de que, ou os canais normais para mudanças já não funcionam, e que as queixas não serão ouvidas nem terão qualquer efeito, ou então, pelo contrário, o governo está em vias de efetuar e se envolve $e$ persiste em modos de agir cuja legalidade e constitucionalidade estão expostas a graves dúvidas (idem, pp. 68-69, grifos meus).

Fenômeno recorrente na década de 1960, a desobediência civil se caracteriza por ser praticada em grupo, por minorias organizadas que se posicionam publicamente contra a política do governo e, claro, contra a opinião corrente da maioria esmagadora da sociedade (cf. idem, p. 55). A ação que realizam em concerto brota de um compromisso mútuo e visa sempre o interesse de um grupo e não um interesse particular (cf. idem, p. 69). A ação dos contestadores não é violenta e, em sua maioria, não rejeita a estrutura legal do país. Podem agir com vistas a pressionar o governo para manter o status quo quando, por exemplo, algum direito constitucional está em vias de ser violado, como podem agir com vistas a pressionar o governo para que as instituições sejam porosas às novas demandas dos cidadãos, para que haja mudanças (cf. idem, ibidem). Ao exigirem mudanças, os contestadores civis testam o quanto "as instituições da liberdade são ou não são bastante flexíveis para sobreviver ao violento ataque da mudança sem guerra civil ou revolução" (idem, p. 74).

O movimento pelos direitos civis e o movimento estudantil são casos de minorias organizadas que se associaram para exigir publicamente que os negros fossem tornados legalmente cidadãos no sul do país, que thes fosse assegurado direitos civis. Dois fatos se tornam aparentes a partir dessas experiências de ação política. Primeiro, “a lei realmente pode estabilizar e legalizar uma mudança já ocorrida, mas a mudança em si é sempre resultado de ação extra-legal” (idem, p. 73), ou seja, o potencial da mudança e sua possibilidade só pode ser dado pela ação em concerto de pessoas que se associam com vistas a algum objetivo claro e comum. Segundo, ao se associarem, as pessoas não se encontram mais isoladas e impotentes, pelo contrário, são “"um poder visto de longe cujas ações servem de exemplo e cuja linguagem é ouvida”" (idem, p. 85). Desse modo, “os contestadores civis não são mais que a derradeira forma de associação voluntária” (idem, ibidem).

As promessas ou acordos mútuos e os compromissos comuns se tornam "a base para 'associações' - a reunião de pessoas para uma determinada finalidade política" (Arendt, 2011, p. 236); porque o ato de prometer tem um caráter vinculante. Poder e liberdade caminham juntos. A desobediência civil, ao ter a forma de uma associação voluntária, ou seja, ao se basear em um acordo mútuo, mantém e preserva o poder 
criado pelas ações conjuntas, possibilitando, assim, a fundação da liberdade política, isto é, a participação dos cidadãos nos assuntos do governo.

A importância que Arendt confere à experiência política das associações voluntárias constituídas por uma diversidade de pessoas que, a despeito de suas diferenças, são capazes de se reunir e agir em concerto por demandas políticas comuns, deixa claro o quanto o diagnóstico de Margareth Canovan está equivocado. Ao dizer que, porque Arendt mantém o seu foco no totalitarismo - por continuar "a interpretar a política na América dos anos de 1960, em alguma medida, em termos de uma teoria herdada da sociedade de massas e seus perigos políticos" ela vê "uniformidade monolítica nas sociedades ocidentais onde outros enxergam diversidade e pluralismo", a comentadora não percebe que, para Arendt, as sociedades ocidentais não são monoliticamente uniformes. Pelo contrário, apesar de seguirem certos padrões sociais e tenderem a uma homogeneidade crescente justamente porque são uma sociedade de massas, a análise do fenômeno da desobediência civil empreendida pela autora mostra que se houvesse na sociedade americana uma "uniformidade monolítica" em vez de alguma pluralidade e diversidade, os movimentos estudantis e pelos direitos civis sequer seriam possíveis. A pluralidade e a diversidade estavam lá, só precisavam aparecer e o fizeram. Por não perceber que Arendt desatrela a sociedade de massas do fenômeno do totalitarismo, Canovan não percebe o ganho que há em ter alguma pluralidade, diversidade e possibilidade de contestação em comparação a não ter nenhuma. Quando se depara com a afirmação de Arendt de que vivemos sob as condições de uma sociedade massificada, Canovan faz uma ponte direta com o totalitarismo e, por isso, enxerga o total fechamento da esfera pública. Na verdade, Arendt está mostrando que há alguma abertura nessa esfera, afinal, embora não seja plenamente democrática, a sociedade massificada não é necessariamente sociedade totalitária.

Os movimentos de desobediência civil permitem a Arendt enxergar a possibilidade de se criar espaços novos ou alargar os espaços ainda existentes na sociedade de massas, ainda que seja evidente o "declínio do apetite pela ação" (idem, ibidem); declínio que parece ter passado despercebido por Canovan ao afirmar que a análise arendtiana do fenômeno do social, na sua vertente cultural, seria castigada pela teoria da sociedade de massas ao se mostrar preocupada com a "uniformidade da moral e do estilo de vida". Para Canovan, e a seu contragosto, a teoria da sociedade de massas de Arendt estaria embasada na ideia de que a sociedade se comporta. Contudo, a discordância de Canovan parece decorrer do fato dela colocar a tônica da argumentação de Arendt no lugar errado. Se a análise arendtiana estivesse tão somente preocupada com o fato de que as pessoas se tornaram fúteis porque dão mais valor ao status social, ao consumo e ao padrão da moda, ainda assim, sua análise teria muito a dizer sobre as sociedades contemporâneas. Contudo, 
as análises de Arendt têm uma preocupação maior que extrapola o âmbito "cultural" (no sentido que Canovan lhe atribui) e que diz respeito ao declínio da capacidade de ação política, uma vez que "o comportamento substituiu a ação como principal forma de relação humana" (Arendt, 2014, p. 50). Desse modo, acredito que a tônica de Arendt não está tão somente no fato de que as pessoas se comportam, mas, primordialmente, no fato de que não agem porque se comportam. A ênfase está, então, no âmbito político, que vai sendo minado com o avanço e desenvolvimento da esfera social no estágio da sociedade de massas.

Os ensaios "Desobediência Civil” e "Reflexões sobre política e revolução: um comentário" (Arendt, 2013) analisam e destacam a associação voluntária mediada pelo diálogo em concerto dos movimentos pelos direitos civis e estudantil. Em ambos os ensaios, vê-se uma argumentação que, em quase toda a totalidade, se distancia radicalmente da argumentação da obra de 1951 acerca dos movimentos totalitários na medida em que busca mostrar possíveis potenciais democráticos nos movimentos de desobediência civil. Desse modo, a crítica endereçada à autora por Cohen e Arato também é equívoca. Eles afirmam que a análise de Arendt dos movimentos sociais tem como paradigma as experiências dos movimentos totalitários. Como resultado, a autora, os consideraria proto-totalitários, não enxergando, assim, o seu papel mediador entre as esferas pública e privada nas sociedades contemporâneas. A posição dos autores mostra que apenas levaram em conta a argumentação presente em As Origens, deixando de lado a argumentação da obra de 1969. Se Arendt tivesse como paradigma os movimentos totalitários ao analisar os movimentos sociais, não teria visto qualquer potencial político de mudança como efetivamente vê nos movimentos de desobediência civil. Se há na análise de Arendt desses movimentos alguma influência da análise que faz dos movimentos totalitários, essa influência se dá no alerta quanto ao perigo exercido pelas ideologias sobre os movimentos.

Ao levarem em conta apenas a argumentação de As Origens, os comentadores também não perceberam que, em vez de acelerarem e completarem a destruição do domínio público e do privado e alimentarem e perpetuarem a atomização e a despolitização característica da sociedade de massas, o que os movimentos de desobediência civil fazem, por terem a forma de associações voluntárias, é possibilitar o alargamento do espaço público e retirar os indivíduos do isolamento, uma vez que passam a agir em concerto e dialogar entre si sobre questões públicas pontuais que os interessam. A prática da desobediência civil se coloca em oposição direta à apatia, à atomização e ao desinteresse com o domínio público, característicos de uma sociedade massificada. Mais do que isso, Arendt parece apontar que o poder criado pela associação voluntária pode construir uma sociedade que, além de liberdades negativas como direitos civis, garanta o direito de participar ativamente das instâncias decisórias, porque abrem a possibilidade de reivindicar esse direito 
à liberdade positiva; apresentando, assim, potencial para o aprofundamento da democracia.

Reivindicação e contestação não são suficientes para a efetivação da ação política realmente democrática, mas, nas condições atuais de uma sociedade de massas, baseada em uma democracia representativa que se encontra em crise constitucional, elas parecem ser um primeiro passo, pois, quando as instituições falham e perdem a autoridade, as associações voluntárias aparecem como um remédio (cf. Arendt, 2013, p. 90). O passo seguinte seria "encontrar um nicho constitucional para a desobediência civil" (idem, p. 75), reconhecer a legitimidade desses grupos de contestadores e permitir que eles possam "influenciar e 'auxiliar' o Congresso por meio de persuasão, opinião qualificada e pelo número de seus constituintes" (idem, p. 89). Para Arendt, há “"toda probabilidade de ter a desobediência civil um papel progressivamente expansivo nas democracias modernas”” (idem, p. 74).

\section{Considerações finais}

O totalitarismo, embora seja tema presente e perene nas obras de Arendt, não é mais objeto central nas obras de 1963 e 1969. Ambas as obras se voltam para as experiências concretas de ação política do seu próprio tempo, um interesse que parece ter sido despertado em Arendt a partir da Revolução Húngara e sua organização espontânea na forma de conselhos. Seja na análise das conquistas e dos malogros das revoluções modernas americana e francesa em Sobre a revolução, seja na análise dos movimentos de desobediência civil em Crises da república, Arendt está interessada nas experiências de fundação da liberdade e na garantia concreta e institucional dos espaços de ação que permitam o exercício da liberdade positiva e da participação política. 0 contexto não é mais o do totalitarismo, da ausência completa do espaço público e da destruição da humanidade dos indivíduos por meio do terror em conluio com a ideologia totalitária, mas sim o da perda do espírito revolucionário e dos princípios que the fazem parte, como liberdade pública, felicidade pública e espírito público, substituídos pelas "liberdades civis, o bem-estar individual da maioria e a opinião pública” (Arendt, 2011, p. 281). Agora o contexto político é o das sociedades democráticas embasadas no princípio da representação e massificadas.

Embora a sociedade de massas tenha fornecido solo fértil para o domínio total, isso não significa que, para Arendt, toda sociedade de massas seja potencialmente totalitária e vá degenerar em totalitarismo. A sociedade democrática com a qual Arendt se depara, embora não-totalitária (e isso não é trivial), é constantemente ameaçada. Está em jogo a apatia política dos indivíduos ou a ausência de disposição para a ação e o esvaziamento da esfera pública, gerados por governos burocráticos sustentados pela disputa por poder político e pelos interesses privados dos representantes 
partidários. O resultado dessa disputa é deixar à margem da representação e da participação políticas a maioria dos cidadãos, mesmo nas democracias.

As leituras de Margareth Canovan e de Jean Cohen e Andrew Arato revelam, a contrapelo, que a compreensão das obras de Arendt das décadas de 1960 e 1970 exige que se leve em conta a existência de uma diferença significativa quanto à possibilidade da própria política entre sociedade totalitária massificada e sociedades massificadas baseadas no sistema representativo e organizadas em partidos. Não perceber essa diferença nas análises arendtianas leva à desconsideração da possibilidade efetiva dos ganhos democráticos que se abrem na sociedade de massas no mundo contemporâneo.

Embora os impactos e a importância do totalitarismo no pensamento de Arendt sejam inegáveis, convém não permitir que obscureçam a enorme preocupação da autora com o mundo não-totalitário das democracias representativas de massa. Elas são mais do que nunca o nosso presente, assombrado sempre pelo passado totalitário e pelas incertezas do futuro. Negligenciar o fato de que, para Arendt, as sociedades democráticas contemporâneas são ainda sociedades massificadas é fechar os olhos para os obstáculos e desafios ainda presentes para a ampliação do espaço público e para a efetivação da cidadania ativa e participativa. Ao mesmo tempo, negligenciar as tentativas efetivas de ação política, mesmo neste contexto, é fechar os olhos para a capacidade humana de iniciar e desencadear novos eventos a partir da ação conjunta.

\section{Referências}

Arendt, H. (1958). Totalitarian Imperialism: on the Hungarian Revolution. Journal of Politics, 20(1), pp.5- 43.

. (1989). As origens do totalitarismo. Tradução de Roberto Raposo. São Paulo: Companhia das Letras.

. (2008). “A ameaça do conformismo". In: Compreender: formação, exílio e totalitarismo. Tradução de Denise Bottmann. São Paulo: Companhia das Letras.

- (2011). Sobre a revolução. Tradução de Denise Bottmann, $2^{\circ}$ edição. São Paulo: Companhia das Letras.

. (2013). “Desobediência Civil”. In: Crises da república. Tradução de José Volkmann. $3^{a}$ edição. São Paulo: Perspectiva.

- (2014). A condição humana. Tradução de Adriano Correia. $11^{\mathrm{a}}$ ed. Rio de Janeiro: Forense Universitária.

Canovan, M. (1978). The Contradictions of Hannah Arendt's Political Thought. Political Theory, 6(1), pp. 5-26.

University Press. 
Nathalia Rodrigues da Costa

Cohen, J. L., \& Arato, A. (1995). Civil Society and Political Theory. Cambridge, MA: MIT.

Frateschi, Y. (2016). Liberdade política e cultura democrática. Cadernos de Filosofia Alemã, 21(3), pp. 29-50.

Recebido em: 26.06.2019

Aceito em: 14.11.2019

Esta obra está licenciada com uma Licença Creative Commons Atribuição-NãoComercial-

https://creativecommons.org/licenses/by-nc-sa/4.0/

(c) 